\title{
PENGARUH MENDENGARKAN AYAT SUCI AL QURAN TERHADAP TINGKAT KECEMASAN PASIEN SEBELUM TINDAKAN EKSTRAKSI GIGI
}

\author{
Syafrudin Aulia Azhar*, Rahmawati Sri Praptiningsih**, Erna Dwi Agustin**
}

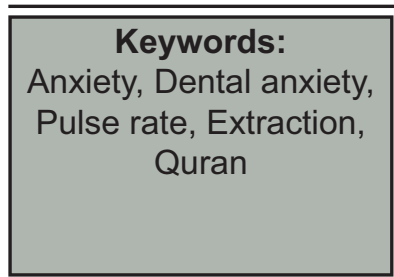

\section{ABSTRACT}

Background: Anxiety is a normal reaction is for the individual against a very pressing situation. Individuals who experience anxiety when visiting the dentist called Dental Anxiety. Dental anxiety due to bad experiences in previous treatments. Physiological signs of anxiety is increased pulse rate. Listening to the Quran can provide a relaxing effect so it can reduce anxiety. The purpose of this study to determine the effect of listening to the Koran on the anxiety level of the patient before tooth extraction.

Method: Quasi experiment study with pre-posttest with control group design was conducted on 38 extraction patient and divided into two groups: a control group that did not listen to the Quran and the treatment group who listened to the Quran before extraction. The pulse rate of control groups were measured at the time when patients came in and 5 minutes later. The pulse ate of treatment group were measured at the time when patients came in and after the patient were listened to Quran. Data were analyzed by Independent T-Test .

Result: The result showed the average pulse rate in the treatment group before and after were 67.26 and 62.68 , while the average pulse rate in the control group before and after were 65.89 and 65.84. Independent T-test results showed $p=0.000$, it's mean that there are significant differences of the pulse rate between the treatment group and the control group on the anxiety level of the patient before tooth extraction.

Conclusion: It can be concluded that listening to the Quran could reduce patient anxiety before dental extraction.

\section{PENDAHULUAN}

Ekstraksi gigi merupakan proses pengeluaran gigi dari dalam soket dari tulang alveolar ${ }^{1}$. Ekstraksi gigi memiliki indikasi yang bervariasi. Sebuah gigi mungkin harus dicabut karena karies, infeksi periapeks, penyakit periodontal, erosi, abrasi, atrisi, atau bahkan kelainan pulpa. Sebuah gigi yang sehat juga harus dicabut sebagai bagian dari rencana perawatan yang akan dilakukan, misalnya perawatan ortodonsi². Indikasi ekstraksi gigi dengan teknik sederhana misalnya gigi berjejal, sedangkan ekstraksi gigi dengan teknik pembedahan misalnya gigi ankilosis ${ }^{1}$.
Masyarakat pada umumnya takut atau cemas saat harus berkunjung ke dokter gigi. Penyebab seorang individu atau pasien mengalami kecemasan saat berkunjung ke dokter gigi adalah pasien mengalami pengalaman buruk saat perawatan gigi sebelumnya, pasien mempunyai perasaan ketidakberdayaan dan kehilangan kontrol, proses pembelajaran sosial, adanya masalah psikologis terhadap individu tersebut ${ }^{3}$. Berdasarkan uraian tersebut dapat disimpulkan bahwa masyarakat atau pasien merasakan kecemasan dan ketakukan terhadap alatalat kedokteran gigi yang digunakan untuk pencabutan gigi. ${ }^{*}$ Program Pendidikan Dokter Gigi Fakultas Kedokteran Gigi Unissula Semarang, ** Staff Pengajar Fakultas
Kedokteran Gigi Universitas Islam Sultan Agung Semarang

Korespondensi: rudiraulia@yahoo.com 
Kecemasan individu ketika berkunjung ke dokter gigi disebut Dental Anxiety ${ }^{4}$. Menurut survei Barlow dan Durand ${ }^{5}$, jumlah ketakutan masyarakat terhadap dokter gigi ada 24 dari 1000 populasi, sedangkan jumlah ketakutan masyarakat terhadap jarum suntik dan rasa sakit ada 31 dari 1000 populasi. Penyebab seorang pasien mengalami kecemasan saat berkunjung ke dokter gigi adalah pasien mengalami pengalaman buruk saat perawatan gigi sebelumnya, pasien mempunyai perasaan ketidakberdayaan dan kehilangan kontrol ${ }^{3}$. Tanda-tanda fisiologis yang dapat timbul pada saat mengalami kecemasan, ditandai dengan meningginya denyut nadi atau berkeringat ${ }^{6}$. Kondisi pasien saat mengalami kecemasan, stres, atau takut dapat ditangani dengan mendengarkan musik atau diberi obat secara farmakologi 7 . Menurut Al-hafidh ${ }^{8}$ dan Handayani, dkk ${ }^{9}$ stres dan cemas dapat ditangani dengan mendengarkan Al Quran karena akan memberikan efek relaksasi.

Secara terminologi atau istilah Al Quran merupakan kalam Allah atau firman Allah yang diturunkan kepada Nabi Muhammad SAW dan membacanya adalah suatu ibadah ${ }^{10}$. Menurut hasil penelitian dari para pakar bahwa akan adanya dampak psikologis dari nada dan langgam terhadap para pendengar ayat suci Al Quran ${ }^{11}$.

Tiga ayat berikut QS. Az Zumar:23, QS.Ar Ra'du:28 dan QS.Al A'raf:204, terdapat di dalam Al Quran yang memiliki makna bahwa setiap manusia yang mendengarkan ayat suci Al Quran atau berzikir kepada-Nya akan mendapatkan ketenangan jiwa. Oleh Sebab itu, dengan memperhatikan banyaknya pasien yang mengalami kecemasan saat akan dilakukannya pencabutan gigi oleh dokter gigi, maka salah satu alternatif dari permasalahan ini adalah dengan menggunakan fungsi dan manfaat dari mendengarkan ayat suci $\mathrm{Al}$ Quran.

\section{METODE PENELITIAN}

Jenis penelitian ini menggunakan rancangan kuasi eksperimen dengan desain penelitian pre-posttest with control group yang bertujuan untuk mengetahui pengaruh mendengarkan ayat suci Al Quran dalam menurunkan kecemasan pasien sebelum ekstraksi gigi. Dalam penelitian ini terdapat kelompok perlakuan dan kelompok kontrol yang digunakan sebagai pembanding untuk memberikan pemahaman mengenai efek perlakuan. Rancangan ini dilakukan secara non random, artinya adalah anggota kelompok perlakuan dan kelompok kontrol tidak dilakukan secara acak. Pada kedua kelompok tersebut dilakukan pretest. Setelah manipulasi dilakukan posttest, dimana diharapkan ada perbedaan dari hasil yang didapat. Menurut Marliani ${ }^{12}$, desain ini direkomendasikan dalam melakukan penelitian terhadap manusia. Rancangan ini merupakan rancangan yang peramalan hasilnya kuat $^{13}$. Metode pengambilan sampel pada penelitian ini adalah purposive sampling. Penelitian dilakukan di Klinik Dokter Gigi drg. Syaiful Azhar, Ngalian, Semarang. Waktu penelitian akan dilaksanakan pada tanggal 1-12 januari 2016. Peneliti menggunakan subjek sebanyak 38 responden yang dibagi menjadi 2 kelompok yaitu 19 subjek untuk kelompok perlakuan dimana pada kelompok ini didengarkan ayat suci Al Quran dan 19 subjek untuk kelompok kontrol dimana tidak diperdengarkan ayat suci AI Quran. 


\section{HASIL PENELITIAN}

Hasil pengukuran denyut nadi sebelum maupun setelah perlakuan diperoleh hasil analisis data sebagai berikut:

Tabel 1 diketahui rerata denyut nadi pada kelompok perlakuan sebelum dan sesudah sebesar 67,26 dan 62,68 , sedangkan rerata denyut nadi pada kelompok kontrol sebelum dan sesudah 65,89 dan 65,84. Hasil tersebut menunjukan adanya penurunan rerata denyut nadi yang lebih tinggi pada kelompok perlakuan daripada kelompok kontrol.

Berdasarkan tabel 3 dapat dilihat bahwa denyut nadi pada kelompok perlakuan menunjukkan adanya perbedaan antara sebelum dan sesudah perlakuan $(p=0,000)$, karena nilai $p<0,05$. Denyut nadi sesudah mendengarkan ayat suci AI Quran lebih rendah daripada sebelum mendengarkan ayat suci $\mathrm{Al}$ Quran. Sedangkan pada kelompok kontrol, denyut nadi sebelum dan sesudah perlakuan tidak menunjukkan adanya perbedaan $(p=0,853)$, karena nilai $p>0,05$ dan denyut

Tabel 1. Rerata pengukuran denyut nadi pada kelompok perlakuan dan kontrol (N1=19 \& N2=19)

\begin{tabular}{lcc}
\hline \multirow{2}{*}{ Kelompok } & Sebelum & Sesudah \\
\cline { 2 - 3 } & Rerata \pm Std.Deviasi & Rerata \pm Std.Deviasi \\
\hline Perlakuan & $67,26 \pm 1,91$ & $62,68 \pm 1,56$ \\
Kontrol & $65,89 \pm 2,33$ & $65,84 \pm 2,16$ \\
\hline
\end{tabular}

Tabel 2. Hasil uji distribusi normalitas data

\begin{tabular}{llll}
\hline Kelompok & & Sig & Ket \\
\hline Perlakuan & Sebelum & 0,591 & Data berdistribusi normal \\
& Sesudah & 0,334 & Data berdistribusi normal \\
Kontrol & Sebelum & 0,454 & Data berdistribusi normal \\
& Sesudah & 0,344 & Data berdistribusi normal \\
\hline
\end{tabular}

Tabel 3. Rerata penurunan denyut nadi pada kelompok perlakuan dan kelompok kontrol (N1=19 \& N2=19)

\begin{tabular}{lccc}
\hline \multirow{2}{*}{ Kelompok } & \multicolumn{3}{c}{ Rerata \pm Std.Deviasi } \\
Perlakuan & Sebelum & Sesudah & p \\
Kontrol & $67,26 \pm 1,91$ & $62,68 \pm 1,56$ & 0,000 \\
\hline
\end{tabular}

Tabel 4. Rerata penurunan denyut nadi pada kelompok perlakuan dan kelompok kontrol (N1=19 \& N2=19)

\begin{tabular}{lcc}
\hline & \multirow{2}{*}{ Kelompok } & Penurunan \\
\cline { 2 - 3 } & Rerata \pm Std.Deviasi \\
\hline Perlakuan & $4,58 \pm 1,77$ \\
Kontrol & $0,05 \pm 1,22$ \\
\hline
\end{tabular}

Tabel 5. Independent t-test

\begin{tabular}{lllll}
\hline & Kelompok & N & Sig & Ket \\
\hline Penurunan & Perlakuan & 19 & \multirow{2}{*}{0,000} & \multirow{2}{*}{ Berbeda bermakna } \\
& Kontrol & 19 & & \\
\hline
\end{tabular}


nadi sebelum dan sesudah mendengarkan ayat suci Al Quran relatif sama. Hal ini berarti perlakuan mendengarkan ayat suci Al Quran dapat menurunkan tingkat kecemasan pasien sebelum ekstraksi gigi.

Pada tabel 4 dapat dilihat bahwa rerata penurunan denyut nadi pada kelompok perlakuan sebesar 4,58 lebih tinggi daripada penurunan denyut nadi pada kelompok kontrol sebesar 0,05.

Hasil uji Independent t-test(tabel5) diperoleh nilai sig sebesar 0,000 ( $p<0,05$, hipotesis diterima) sehingga berarti ada perbedaan penurunan denyut nadi yang signifikan antara kelompok perlakuan dan kelompok kontrol terhadap tingkat kecemasan pasien sebelum tindakan ekstraksi gigi. Dengan demikian dapat diartikan bahwa mendengarkan ayat suci Al Quran efektif dalam menurunkan tingkat kecemasan pasien sebelum tindakan ekstraksi gigi.

\section{DISKUSI}

Hasil ini sesuai dengan isi dari ayat suci Al Quran QS. Az Zumar:23 dan QS. Ar Ra'du:28 dimana memiliki makna bahwa setiap manusia yang mendengarkan ayat suci Al Quran atau berzikir kepada-Nya akan mendapatkan ketenangan jiwa. Hal tersebut juga didukung oleh dasar teori dimana jika seseorang diperdengarkan Al Quran dengan irama yang stabil dan dilakukan dengan tempo yang lambat serta harmonis, maka akan memunculkan ketenangan. Berdasarkan hasil penelitian sebelumnya yang telah dilakukan dan dibuktikan, orang yang membaca $\mathrm{Al}$ Quran atau mendengarkan akan memberikan perubahan arus listrik di otot, perubahan sirkulasi darah, perubahan detak jantung dan perubahan kadar darah pada kulit. Dengan membaca atau mendengarkan Al Quran akan memberikan efek relaksasi, sehingga denyut nadi dan detak jantung mengalami penurunan?

Terapi ayat suci Al Quran ketika diperdengarkan pada orang atau pasien akan membawa gelombang suara dan mendorong otak untuk memproduksi zat kimia yang disebut neuropeptide. Molekul ini akan mempengaruhi reseptor di dalam tubuh sehingga hasilnya tubuh merasa nyaman ${ }^{9}$.

\section{KESIMPULAN}

Dari hasil penelitian dan pembahasan yang telah dilakukan dapat disimpulkan bahwa mendengarkan ayat suci Al Quran dapat menurunkan tingkat kecemasan pasien sebelum ekstraksi gigi secara bermakna.

\section{DAFTAR PUSTAKA}

1. Ferawati, Simfo. 2011. Kontra Indikasi Pencabutan Gigi Hubungannya Dengan Penyakit. Medan: Universitas Sumatera Utara.

2. Howe, Geoffrey L. 1999. Pencabutan Gigi Geligi ( The Extraction of Teeth). Jakarta: EGC. Viii, 110 hlm.

3. Schuller, Annemarie A.,Willumsel, Tiril and Holst, Dorthe. 2003. Are there differences in oral health and oral health behaviour between individuals with high and low dental fear? Community Dentistry and Oral Epidemiology. 31: 116-21.

4. Anonim. 2010. What is Dental Anxiety and Phobia?, Columbia University College of Dental Medicine [online]. Terdapat di: http://www. dentalfearcentral.org/what_is_dental_phobia. html [18 Juli 2015]

5. Barlow, H.D. dan Durand, V.M. 2007. Essentials of Abnormal Psychology. Yogyakarta: Pustaka Pelajar.

6. Pontoh, B. I., Pangemanan, D. H., dan Mariyati, N. W. 2015. Hubungan Tingkat Kecemasan Dengan Perubahan Denyut Nadi Pada Pasien Ekstraksi Gigi Di Puskesmas Tuminting Manado. Jurnal e-GiGi (eG).

7. Djohan. 2006. Terapi Musik Teori dan Aplikasi. Galangpress; Yogyakarta.

8. Al-hafidz, Ahsin W. 2007. Fikih Kesehatan. 
Jakarta : AMZAH

9. Handayani, R., Fajarsari, D., Asih, D. R., dan Rohmah, D. N. 2014. Pengaruh Terapi Murottal Al-Qur'an Untuk Penurunan Nyeri Persalinan Dan Kecemasan Pada Ibu Bersalin Kala I Fase Aktif. 8 Bidan Prada : Jurnal IImiah Kebidanan. 5(2):1-15.

10. Hakim, Abdul dan Hasrul. 2011. Pengertian Al Quran serta Perbedaannya dengan Hadis Qudsi dan Hadis Nabawi. Jakarta: Institut Perguruan Tinggi IImu Al Quran Jakarta.

11. Shihab, M. Quraish. 1998. Mukjizat Al Quran
Ditinjau dari Aspek Kebahasaan, Isyarat IImiah, dan Pemberitaan Gaib. Bandung: Mirzan

12. Marliani, R. 2013. Psikologi Eksperimen. Bandung: Pustaka Setia.

13. Budiharto. 2008. Metodologi Penelitian Kesehatan dengan Contoh Bidang IImu Kesehatan Gigi. Jakarta: EGC. 